\title{
FES Gene
}

National Cancer Institute

\section{Source}

National Cancer Institute. FES Gene. NCI Thesaurus. Code C45497.

This gene is involved in hematopoiesis and the maintenance of cellular transformation. 